\title{
"IF HE BE NOT HIMSELF THE AGE TRANSFIGURED": The Poet, the “Cultivating Class,” and Whitman's 1855 "SONG OF MYSELF"
}

\section{Barbara M. Clancy}

WhitMan CLAimed HIS 1855 POEM that he later called "Song of Myself" "deliberately and insultingly ignored all the other, the cultivated classes as they are called," the better to show that "the genius of the United States is ... most in the common people." Of course, refined, upperclass individuals are represented here, but they are described by a speaker who claims connection not with the cultural elite but with "the endless races of working people and farmers and seamen" (44) that fill the poem. Yet when Whitman grounds his vision of a unified America in the actions of its working people, he must also protect them from contemporary economic stresses that were making it increasingly difficult for reallife workers - his intended readers - to satisfactorily define themselves by what they did for a living. Moreover, he also has to downplay sectional conflict, for if finding self in work was no longer possible, regional rivalry was offering Americans new parameters for self-definition based on increasingly deep divides between party and reform ideologies, slave and free states, and federal and states' rights.

Defying these trends, Whitman removes his working class from his own rapidly changing present in two ways. First, he peoples his poems not with unique individuals caught in a particular historic moment but with human "types"-idealized and ahistoric examples of a wide variety of occupations and conditions. Secondly, he locates each individual in his or her "place," a geographic and temporal position specific to that particular person. Type and place work together to emphasize that each individual occupies a unique and valuable place in an orderly whole. Whitman thus evades the upheavals of his present and preserves his vision of America as a nation whose glorious future is assured by the present-day potentialities incarnated in its working people. Yet to label his subjects by type and place means that the speaker separates himself from them, and his vision and condition thus constantly contradict theirs: he loafs while they labor, speaks while they are voiceless, and wanders through the nation observing them at work and play while they themselves have no such mobility. 
Where, then, is the common ground between the poet and his people? Those passages of "Song of Myself" where the speaker comes closest to sharing in the labor of his subjects provide one answer. In these passages, work and play are never far apart, and this places the speaker, whose own poetic work has a decidedly playful cast, not as an observant emissary from the cultured classes but as an equal member in a "cultivating class" in which physical and intellectual work are not opposites but equally important to the nation's well-being. Such a class, in turn, validates the poet's own work, tearing down all oppositions: body versus soul, male versus female, nature versus society. By doing so, the poet negates the growing political oppositions that have put both his nation and his vision in peril: North versus South, master versus slave, and capital versus labor.

Whitman's attack on oppositional categorization begins as soon as his speaker appears in the notebook lines, "I am the poet of slaves / And I am the poet of the masters of slaves." 3 From then on, the speaker consistently claims to encompass two opposites or speak for people on both sides of a social — or even biological—divide: "I am the poet of the body, / And I am the poet of the soul"; "I am the poet of the woman the same as the man" (46). By doing so the speaker cancels those oppositions: body/soul, male/female, city/country and nature/society are not, in this work, invariably in conflict, nor does the speaker consistently represent only one half of the pair-there are no obvious "others" here. Even the speaker's relationship with the grammatically opposing, mutable "you" is based on mutuality, often to the point of interchangeability, whether that "you" is a mystical lover whose penetration of the speaker in Section 5 awakens him to his connection with all creation, or half of the traditionally hierarchical dyad of student and master: "He most honors my style who learns under it to destroy the teacher" (83). Instead, by claiming to speak of and for both men and women, body and soul, and "goodness" and "wickedness," Whitman attacks a construction of reality based on privileging one half of an opposition over the other, not just in national politics but within any individual who is forced to deny any part of his or her nature to fit social expectations. The lonely woman of Section 11, for instance, inhabits a world where the oppositions between nature and culture and male and female dictate that while men will have certain freedoms, women will be denied them, and a well-to-do and "richly drest" (36) woman cannot retain class privileges and at the same time enjoy direct, unmediated contact with the natural, sensual world of working-class men (or the lower-key sensuality of their shortcake-baking daughters and nursing wives). The woman's solution is to become "the twenty-ninth bather," an imaginative transformation that transcends social boundaries between genders, classes, and bodies and their environments. 
Similarly, Whitman challenges the opposition between high and low culture by basing his speaker on the 1840s urban folk figures of the b'hoy and loafer. As David S. Reynolds observes, in the process of incorporating these figures into the character of his speaker, Whitman mutes some of their least-respectable attributes, especially the b'hoy's love of fighting. ${ }^{4}$ In fact, Whitman takes certain loafer characteristics to such extremes that his speaker begins to resemble the high-culture ideal of the poet as an individualist aloof from society: if the loafer is a folk philosopher disengaged from the getting and spending of his time, the speaker is a visionary with no job or history, whose travels encompass all of North America and recorded time. At the same time, Whitman's initial self-description, the frontispiece engraving, is defiantly workingclass: this portrait, as one reviewer sniffed, "expresses all the features of the hard democrat and none of the flexile delicacies of the poet." ${ }^{5}$ This was not a fatuous remark - one hallmark of the civilized (and therefore serious) poet, circa 1855, was a disdain for what Betsy Erkkila has called the "bric-a-brac of the modern world." Erkkila notes that Whitman's contemporaries had largely failed to find poetic inspiration in urban working-class life; ${ }^{6}$ even Emerson and Thoreau thought the masses too far gone in conformity and materialism. Through the design of Leaves of Grass, Whitman asserted otherwise: the juxtaposition of the engraving, the city name, and the year implies that the author is not only a typical Brooklyn workingman, but the essence of the city itself, anticipating his assertion "I am large . . . I contain multitudes" (87), and that the poems are themselves less the production of any one person than a reflection of that person's particular place and time. Moreover, the directness of the portrait's gaze and his almost pugilistic pose emphasize his determination to craft his own, equally worldly, poetic agenda, one that encompasses "the blab of the pave" (49) as well as Emersonian inspiration from nature.

Thus from the inception of the poem the speaker insists on his ability to transcend the perceived opposition between high and low culture and body and soul. As soon as the frontispiece image speaks he disassociates himself from his class and time: we first find him not in Brooklyn in 1855 but vowing to go to the woods and along the riverbank where "undisguised and naked" (27) he explores the permeable boundary between the human body and the natural world. His initial inspiration is nothing man-made, but a simple "spear of summer grass" (27). Moreover, when he defines his essence, the "Me myself," he does so in a passage that seems to isolate that essence from the world of custom and manner in precisely the way that Emerson hoped his poet would. In Section 4 he says:

Trippers and askers surround me,

People I meet . . . . the effect upon me of my early life . . . of the ward and city I 
live in .... of the nation,

The latest news ... . discoveries, inventions, societies . . . . authors old and new,

My dinner, dress, associates, looks, business, compliments, dues,

The real or fancied indifference of some man or woman I love,

The sickness of one of my folks - or of myself . . . or ill-doing . . . or loss or lack of

money .... or depressions or exaltations,

They come to me days and nights and go from me again,

But they are not the Me myself. (29-30)

As the rest of the poem makes clear, Whitman's separation of the Me myself from everyday life is not based on disdain for the world. Instead, the speaker seeks to define the self as an entity immune to historic change and resistant to easy interpretation, for as M. Wynn Thomas notes, to acknowledge one's origins leaves one open to the kind of definition by others that in a materialistic culture is ultimately constricting and reductive. ${ }^{7}$ The speaker therefore separates himself from those aspects of life that mark the individual's place in history (either personal, national, or literary), in a geographic location, in an occupation, or in a class. By disavowing "the effect upon me of my early life .... of the ward and city I live in . . . of the nation," he separates himself not only from his own life story-his family's history, its recent disappointments, his father's political beliefs, and his own attempt to influence opinion and policy through journalism and fiction-but also from that personal history's intersection with the issues of his day. ${ }^{8} \mathrm{By}$ separating himself from "authors old and new," he places himself apart from both the literary past and present. By breaking the link to "dinner, dress, associates, looks, business, compliments, dues," the speaker evades many possible categorizations, but chiefly categorization by occupation. Certain nouns in the string suggest a white-collar job-we would not expect the working-class man depicted on the frontispiece to be concerned with dress, associates, looks, or compliments as a part of his working life. Thus the passage universalizes the speaker, widening his potential class background at the same time that it emphasizes his determination to define himself apart from class and job status. As a result the poet of the Me myself is always in the present, not a part of the literary community or of any community, professional, regional, or familial. Without ties to any subset of society he cannot be easily defined and thus is free to define himself. Hence,

Apart from the pulling and hauling stands what I am,

Stands amused, complacent, compassionating, idle, unitary,

Looks down, is erect, bends an arm on an impalpable certain rest,

Looks with its sidecurved head curious what will come next,

Both in and out of the game, and watching and wondering at it. (30)

As essentialist as this definition of selfhood may seem, it is, of course, also a moment that returns us to the "hard democrat" and workingman 
of the frontispiece, for as Erkkila has observed, this pose-erect, arm bent, "sidecurved" head-is almost an exact description of Whitman's pose in the frontispiece engraving. ${ }^{9}$ Moreover, it is a quintessential workingman's position: when he stands and "looks down . . . curious what will come next, / Both in and out of the game, and watching and wondering at it," he is in the same position as any framer, mason, or roofer taking a break from his work on the upper stories to consider the life below him. Thus achieving this position is neither an end in itself or a step in a linear process, but a link between laborer and eternal $\mathrm{Me}$ myself that confirms both the visionary potential of the former and the real-life rootedness of the latter. Now, having removed himself from social categorization in Section 4, reconnected himself to his "brothers ... sisters and lovers" (31) and the limitlessness of creation in Section 5 , explored the nation and merged with its people and natural environments, the speaker is able to name himself and to assert the connections that really matter to him. In Section 24 he pronounces himself

Walt Whitman, an American, one of the roughs, a kosmos,

Disorderly fleshy and sensual .... eating drinking and breeding,

No sentimentalist . . . . no stander above men and women or apart from them . . . .

no more modest than immodest. (50)

By building this self-description on a recognition of the power of conventional oppositions to order thought, Whitman subverts those oppositions: by stating what he is in the naming passage, Whitman tacitly emphasizes the other half of the social opposition or what he is not. Importantly, however, he does not claim that these categories are mutually exclusive, but that one has "assumed" the other-has received from it what is useful and made that a part of itself. Thus, we are not only reminded that he is of the new world as opposed to the old, one of the roughs as opposed to a gentleman, a kosmos as opposed to the romantic ideal of the poet as an individual separate from or at odds with society, and a force of nature rather than an exemplar of culture, but that the speaker values the contributions of the old world and its ideals to himself and his time: like the ancient gods of Section 41 "they were alive and did the work of their day" (74). The pulling and hauling from which he stands apart are therefore not simply the busywork of the world, but that aspect of cultivated society that orders reality through the deforming use of hierarchical, antagonistic oppositions and therefore denies that the "new life of the new forms" (5) of America's people and poetry are the rightful heirs of the old world and its styles, both aesthetic and political. Such a viewpoint also denies the unified self that emerges in the first half of the poem, for Whitman's "cultivated class" sees individuals not as wholes whose labor-whatever form it takes-is indivis- 
ible from play and sensuality, but as workers in jobs, chattel slaves, and women held apart from their physical nature, whether sexual or generative, by propriety. ${ }^{10}$

Whitman's desire to transcend oppositions also informs his descriptions of his largely working-class subjects. For Whitman, work is not a struggle against nature but the natural action of men and women. ${ }^{11} \mathrm{Just}$ as the body of the speaker easily merges with the natural world around him, the same lack of conflict with the environment marks his descriptions of labor in the poem: "Song of Myself" creates a world without dull blades, damp wood, stubborn horses, or colicky infants. Whitman does not merely ignore the occasional "bad day's work" (102), however; as M. Wynn Thomas and Alan Trachtenberg have noted, he also largely ignores the labor market. ${ }^{12}$ Whitman's description of "Many sweating and ploughing and thrashing, and then the chaff for payment receiving, / A few idly owning, and they the wheat continually claiming" (76) is an indictment of antebellum economics, to be sure, but it is imaged abstractly, without portraying individual workers. Thus Whitman's description of antebellum work and worker is, as Thomas has said of the broad-axe, "an ingenious image of the ideal, which he can conveniently confuse, or at least credibly connect, with the existing state of affairs"13 - ingenious because Whitman's idealization of labor as action allows the speaker to describe his workers in much the same way as he describes himself. Both descriptions emphasize a divinity linking all people and things, first by showing a self-proclaimed common man linking his physical body to his essential self through every sensation he experiences, and secondly by showing the bodies of dozens of common folk engaged in everyday work or situations, the descriptions of which emphasize simple and evocative visual, tactile, or auditory sensations. Thus the cumulative effect of these descriptions is to again erase the opposition of body and soul: like the grass itself, these people are divine precisely because they are so earthly, and we connect with them because their actions and the loci where they take place are so familiar to us. ${ }^{14}$ We are not privy to the youth's thoughts as he "lies awake in the cedar-roofed garret and harks to the musical rain" (40), nor to those of the bride as she "unrumples" (41) her dress, nor to those of the farmer gazing on his fields, yet it is those common physical actions-lying, listening, waiting, watching - combined with the appeal that the smell of cedar, the sound of rain, the feel of the dress and the sight of the growing crops makes to our own sensory memories that convince us of the depths of these persons' emotional lives and of the existence of their own Me myselves. 
Yet as far as the poem is concerned, these Me myselves do not, like the speaker, articulate their own visions, for, paradoxically, Whitman has drawn these evocative portraits of types: ${ }^{15}$ simple characters existing in a static present tense, without personal histories or social connections. Whitman creates a multiplicity of types by defining his working class as broadly as possible. While working men predominate, there are also slaves, historical figures, mothers, homemakers, frontiersmen, and social outcasts, as well as people enjoying leisure activities, religious observances, and holiday celebrations, emphasizing a lack of division between the individual at work and at play, and between private and public life. Most importantly, however, Whitman does not create complicated characters or include stories of individual adaptation to social conditions. Only the lonely woman in Section 11, the most traditionally narrated section of the poem, defies social expectations, and in her case that defiance takes place in her imagination and in a landscape that, compared to the rest of the poem, is particularly otherworldly. Whitman could have included many more of what Thomas calls "social materials"; that he chose not to do so indicates, for Thomas, a philosophical rejection of what is made "direct or descriptive or epic" (8) through a positivist point of view. ${ }^{16}$ On a more practical level, however, no poet attempting a unified poetic vision of America could afford to spend too much time on developing individual characters reacting to situations; to do so would privilege one competing ideology over another. Instead, the majority of Whitman's subjects have more or less the same characteristics whenever they appear: mothers are calm, workingmen are physically commanding, the rare upper-class representative is impotent or deformed in some way. In "The Poet," Emerson wrote that the transformation of object into symbol reveals new layers of meaning, the essence of poetic language: "Being used as a type, a second wonderful value appears in the object, far better than its old value, as the carpenter's stretched cord, if you hold your ear close enough, is musical in the breeze." ${ }^{17}$ In his use of types, however, Whitman seems to be looking less for symbolic content than consistency, using human types not symbolically, but to support his Preface definition of America as poem (and himself as poet) in much the same way that type itself-letters, punctuation, and even decoration-makes words, poems, and ultimately meaning in the mind of a reader. He selects the people in his poems just as he had often selected letters out of a typecase, making his iconographic characters human letterforms, literally "types" in a font of America. Thus the details of the individual portraits mirror the identifying characteristics of families of type, just as a " $T$ " might be black letter, serif, or script but must also be instantly recognizable as a " $T$ " in order to make the text in which it is set comprehensible. 
For a poet to "type" individuals may at first appear dismissive, but "type" is a favorite word of Whitman's - no ex-compositor would use it casually, and certainly not one who kept Whitman's level of involvement in the design and production of his books. ${ }^{18}$ In "As I Ebb'd with the Ocean of Life," when the speaker walks the beaches "seeking types" (394) but finding only drift and debris, he is unable to call forth any productive vision of the world, and that in turn calls into question his own identity as a poet. Whitman also believed, as a printer and journalist would, in the latent power of type itself. In the poem "A Font of Type," what is lying in the case is "Not nonpareil, brevier, bourgeois, long primer merely," but "unlaunch'd voices-passionate powers . . . ocean waves arousable to fury and to death" (614). Thus Whitman not only endows type with the human potential for communication but merges that potential with natural forces just as he describes work itself as a natural action. When he speaks of the West as "the same old font of type, but set up to a text never composed or issued before" 19 he indicates that a poet "composes" his subjects in order to articulate a univeral truth - that the poet is not so much creator as organizer. It is in this spirit that he assembles his working people.

Having been composed, these types are then read, either by the reader in the one-line vignettes which present the majority of working people in the poem, or, in the longer passages, by the speaker himself, who enters into the bodies of his subjects in order to expand their stories in support of his philosophical position. Thus he speaks for them, either as the storytelling voice of the lonely woman passage and the Goliad massacre, or through them, assuming the personae of the wife of the drowned man, the fireman, the hounded slave, the sailor in battle, and others, so that his promise to "dilate you with tremendous breath" (73) becomes most realized in this pattern of taking on his subjects' identities and then telling their stories. Because these subjects are revealed to the reader only through the speaker's often brief observations, their movements are often limited or repetitive, consisting of no more than can be seen in a moment. This in turn contributes to a sense of stillness in almost all the descriptions of types at work. We see this throughout the poem but most markedly in the long catalogue in Section 15. There is an absence of completed actions in this section-every character is shown in the midst of his or her work and will remain there even when the nature of the work implies an end to the job. This, coupled with the continual use of the present tense, suspends these characters outside the passage of time. "The nine months' gone" will always be in the middle of labor, the purchaser will always "[higgle] about the odd cent" (40). Moreover, this never-ending now and the absence of completed actions blurs the distinction between occupation and condition, so that "carpenter" and "jour printer" become as essential and unchanging identifications as "lunatic" and "quadroon."20 
This sense of stillness is magnified by the subjects' physical state: Whitman depicts many of these individuals at rest, in moments of anticipation, or in reaction to events. At its most extreme, this tendency to focus on rest, anticipation, or reaction results in the large number of characters encountered at the moment of death or loss of consciousness, or in overpowering physical or emotional distress. The fireman, the slave and convict, even the speaker himself at the point where his "fit" masters him, are bound by their common passage from crisis into stillness and silence. Less distressingly, the speaker makes one of his deepest identifications with his subjects when they are at rest in a most normal state, sleep:

The city sleeps and the country sleeps,

The living sleep for their time .... the dead sleep for their time,

The old husband sleeps by his wife and the young husband sleeps by his wife;

And these one and all tend inward to me, and I tend outward to them,

And such as it is to be of these more or less I am. (42)

Sleep removes all divisions between city and country, living and dead, old and young, and ultimately between observer and observed. The essence of the types in Section 15 tends inward to the speaker until "poet" begins to take on the characteristics of an infinite number of occupations, including some of the professional ones absent from the passage: "artist . . . . a gentleman . . . . lawyer, physician or priest" (43). Sleep also removes one last vital division, the "place" of geographic regions. In Section 16, the speaker says he is "One of the great nation, the nation of many nations - the smallest the same and the largest the same, / A southerner soon as a northerner" (42). Though the passage goes on to include many different regions of the United States and ultimately the rest of the world, it is important that the first split the speaker heals is the most troubling to him and, at the time, to the country as a whole, that between North and South, free state and slave state, Yankee trader and southern planter. Thus like type in the bed of a press, Whitman's workers stay put for a purpose, the better to present an optimistic, fertile, active, and ultimately orderly America.

While many of Whitman's critics have noted the painterly quality of his descriptions of individual Americans, both Thomas and Trachtenberg have referred to these descriptions as tableaux vivants, ${ }^{21}$ an appropriate term, since the tableau vivant emphasizes the same tension between life and stillness that animates the most evocative descriptions of humanity in "Song of Myself." But in a different sense, the tableau vivant, or literally "living table," is a tool for imposing order, a strategy for containing folk in a society that offers escape routes for the individual, mythic or otherwise, West, North, or up the socioeconomic ladder. ${ }^{22}$ As Michel Foucault writes, organizing the masses so that they 
and their activities can be seen is "the first of the great operations of discipline," transforming "the confused, useless, or dangerous multitudes into ordered multiplicities." ${ }^{23}$ The multitudes of 1855 were not yet dangerous, but were certainly confused-wondering how sectional difficulties could be mitigated, and, as far as the working class was concerned, how to handle the economic and technological changes that were creating new occupations while marginalizing and reducing the status of the old-style craftsman. Just as the dramatic tableau vivant could simplify and impose its own meaning on whatever religious or historical scene it depicted, Whitman's "living tables" order his America based not on a realist's implied ideological position or on the reductive categorization of the cultivated class, but on the sovereignty of the individual, as the speaker- "afoot with my vision" (59) — transmits what he sees to us.

Whitman's tables also unite speaker and subject when he, too, insists that he occupies a unique "place":

I resist anything better than my own diversity,

And breathe the air and leave plenty after me,

And am not stuck up, and am in my place.

The moth and the fisheggs are in their place,

The suns I see and the suns I cannot see are in their place,

The palpable is in its place and the impalpable is in its place. (43)

Whitman has already stated that everything in the universe is connected, and that we are all "immortal and fathomless" (33). Yet to say in addition that everything is "in its place" introduces a sense of order and rightness to society which again negates the effect of historical change on individuals, regions, races, and classes. It is important to stress that Whitman believes no one place is better than another; although this passage moves hierarchically from moth to suns to the impalpable, he is claiming what might be called a hierarchy of equals: "That which fills its period and place is equal to any" (79). Nevertheless, the political consequence of Whitman's concept of place is that it is difficult for him to combine the actualities and the potentialities of America in one poem without implicitly condoning institutions that imperil his democratic vision; as Erkkila notes, Whitman's belief in free enterprise means his poetry can't address some pressing social problems. ${ }^{24}$ These include the growth of an urban underclass, inequitable economic development, and the destruction of the western wilderness and its people, all of which were subject matter for other writers, including Whitman himself in his journalistic days. Thus, while he sympathizes with the prostitute in Section 15, he doesn't act on her behalf, possibly because he is intrigued with the urban demi-monde of which she is a representative: "Arrests of criminals, slights, adulterous offers made, acceptances, rejections with 
convex lips, / I mind them or the resonance of them ... . I come again and again" (34). Industrialization gives us the "cleanhaired Yankee girl"(40), though by 1855 New England mill owners had discovered that immigrants would work for less pay than New England farm girls; moreover, Whitman himself had written reform journalism castigating mill owners for poor treatment of their female employees. ${ }^{25}$ "Song of Myself" also idealizes western expansion as the merge of the American people with their landscape, while neglecting to note that it was Whitman's urban laborers who were among the most eager to start homesteading and were prevented from doing so by a government committed to preserving a low-wage city workforce. ${ }^{26}$ Whitman writes, "I am enamoured of growing outdoors, / Of men that live among cattle or taste of the ocean or woods" (38), seeing no ill effects from the presence of settlers, either to the native people displaced by them, ${ }^{27}$ or to the wilderness itself, although its loss, particularly through deforestation, was a common theme in literature, song, and painting. ${ }^{28}$

The only social ill that Whitman can't avoid in "Song of Myself" is slavery. Yet while Whitman's portrayals of African-Americans are revolutionary for the degree of identification between speaker and subject, they are also limited by Whitman's desire to avoid antagonizing either North or South. For instance, while Whitman does attack slavery in his Preface and shows the speaker's interaction with two fugitive slaves, he does not write about any slave who has freed himself by successfully escaping North, a surprising omission considering Whitman's own attack on slavery in the Preface, and how widely escape narratives and anti-slavery fiction were read in the antebellum period. ${ }^{29}$ Instead, one slave is caught and brutally punished, while we see the other only as he passes through the speaker's home. Both escape narratives and antislavery fiction commonly depict sympathetic whites aiding black runaways, yet Whitman's handling of this form is different from the norm. ${ }^{30}$ His action seems inspired less by any religious or political conviction than a self-conscious desire to show his own capacity for benevolence, as he combines his humane treatment of the slave and his wounds with the rather lordly tone of lines such as "And gave him a room that entered from my own, and gave him some coarse clean clothes, / And remember perfectly well his revolving eyes and his awkwardness, / . . . I had him sit next me at table . . . my firelock leaned in the corner" (35-36). The interaction between speaker and fugitive remains almost completely nonverbal, in contrast to the majority of escape narratives where the ex-slave's first conversation with whites as an equal is a mark of his new status as a free man. Moreover, what happens to the fugitive after he leaves the house-the momentous change in status from runaway chattel to man among men-is not important. This absence of a connection between personal and national history means that ultimately 
the passage is less about the slave than the power of the speaker to sympathize with someone whom many of his intended readers would have considered either a criminal or subhuman.

Similarly, in the portrait of the black teamster Whitman ignores what would be vital information to almost any antebellum author-the man's legal status. If he is a freedman we don't know how he came to be one, where he now lives, whether his family is with him, or the extent to which he can enjoy his freedom. If he is a slave, by not mentioning the fact, Whitman ignores the potential irony of the contrast between his indomitable demeanor and his legal status (a contrast which he makes in "I Sing the Body Electric"). Instead, Whitman again chooses to emphasize the present only, focusing on the teamster's mastery over his immediate situation rather than detailing his personal history, as if to say his freedom, whatever legal form it may take, is best expressed through his physical bearing. Thus he "holds firmly the reins of his four horses," standing "steady and tall" with a "calm and commanding" glance (37). The nobility of this portrait is somewhat undercut by the concluding descriptive term "picturesque giant" (37); yet when the speaker follows the team, he begins to make his passage into the catalogue of Section 15 , a passage that ends with the speaker claiming connections with all of the myriad types he describes, which makes the teamster, in a sense, the initiator of the speaker's connectedness. ${ }^{31}$ Thus Whitman's omission of a conventionally-structured escape narrative not only evades the most volatile political issue of his day, it is also unnecessary, considering how he works with idealizing concepts such as type and place in order to hint at the possibility that individuals-beginning, of course, with the speaker and reader of the poem-could make momentous changes in their consciousness, if not in their social conditions.

Thus for Whitman to say that everything has been, is, and always will be in its place is both a means of containing and empowering common Americans. Type and place preserve a sense of the importance of the individual soul and deny the disturbing effects of recent historical change, for all individuals are equally noble despite their race, enslavement, poverty, or low-status occupation. Recent economic changes, recent social change, and sharper conflicts between slave and free states don't matter.

The problem with Whitman's assertion is, of course, that economic transformation, westward expansion, and the social upheavals they cause, do matter, to the slave, the freedman, the slave owner, the unemployed journeyman, the small-time capitalist, or any American whose expectations were changing in unforeseen ways during the antebellum period. And whether or not this conflict between the idealized working world of the poem and the real-life conditions and value of labor-free, women's, and slave-is the start of what Thomas identifies as Whitman's ever- 
widening distance from his fellow Americans, ${ }^{32}$ it is clear that even the 1855 version of Whitman's speaker places himself at a distance from his subjects' working lives. For if Whitman's vision of America is based in a portayal of its citizens as types indivisible from their environment and expressing themselves not through voice but through labor, what can they possibly have in common with a speaker who roves everywhere, is never silent, and, moreover, never completely joins in with the work that he sees being done?

The obvious answer is that the entire poem is built around a vision supported by the speaker's wide-ranging and uninhibited observations. If he'd been hard at work at anything, especially writing poetry, we'd have no poem, or at least not "Song of Myself." But at one point in the poem the speaker seems to claim a connection to the working world that his actions don't support. By looking at the discrepancy between what the speaker says and what he does, we can better see exactly what Whitman imagined a poet's work had in common with the daily labors he catalogued in such detail. In Section 9 we see the speaker helping with the haymaking:

The armfuls are packed to the sagging mow:

I am there . . . I help . . . . I came stretched atop of the load,

I felt its soft jolts .... one leg reclined on the other,

I jump from the crossbeams, and seize the clover and timothy,

And roll head over heels, and tangle my hair full of wisps. (34)

Whitman's use of the phrase "I help" is, at first, curious, for the speaker offers very little help at all. In fact, he relives his actions in the opening lines of the poem, loafing "atop of the load" observing the grass. One may read the phrase "I help" as acknowledging that while haymaking is hard work, it is also potentially a community job, something like the "apple-pealings ... and huskings and houseraisings" (61) the speaker visits later in the poem. Thus this work is an opportunity for people to get together and enjoy not only the communal aspect of the work that they do, but indulge in any opportunities for play that the work offers. An accepted aspect of this situation is that some of the individuals involved are going to fool around more than others, for this is work that acknowledges individual character, be it serious or silly. The connection between work and play continues in Section 10: "The boatmen and clamdiggers arose early and stopped for me, ... / You should have been with us that day round the chowder-kettle" (35). In those lines we see neither poet nor fisherman at work. Instead, the work is an opportunity for socializing, for experiencing labor as community, and, importantly, a community that extends outside the trade to include the speaker of the poem, and, by extension, any person who can attain the speaker's sense of connection with others. Likewise in that section, when the 
speaker, sailing on the Yankee clipper, says "I bend at her prow or shout joyously from the deck" (35), he is again experiencing the potential for moments of beauty and joy within labor, just as the grass in Section 9 is beautiful, "brown gray and green intertinged," soft and inviting, and provokes a particularly playful moment: "I jump from the crossbeams, and seize the clover and timothy, / And roll head over heels, and tangle my hair full of wisps."

Nevertheless, the speaker's actions in Section 9 are too far from any possible practical definition of "help"; moreover, in this social work setting, the speaker is not only the sole individual taking the opportunity to entertain himself, he is literally the only one there. ${ }^{33}$ Practically speaking, of course, there have to be other people working; when Whitman says that "the dried grass of the harvest-time loads the slowdrawn wagon" he does not mean that it loads itself, though the unexpectedly active verb does emphasize the hay's exceptional nature. But as a result of his meditations on grass and his vision of both individual divinity and divine community, the poet experiences haymaking on an entirely different plane from the people doing the work, to the point that his body and the bodies at work barely occupy the same space.

That distance from the work at hand points to a definition of "help" peculiar to poets. Farmhands fill haylofts, and poets link the task and the hay itself to a network of images and ideas about how the world works. No one work is nobler than the other: follow the speaker and "you shall possess the origin of all poems" (28), but follow a farmer and you may learn something about how to express those origins, as the speaker does. This exchange of expertise is not in itself the "bartering of being for being" that Trachtenberg imagines to be Whitman's ideal poetic economics, ${ }^{34}$ for the haymaking episode is just one of many contributing to the poet's vision while it leaves the farmers faceless and voiceless. Nevertheless it valorizes the farmers as producers not just of a valuable commodity but of images and sensations that resonate through the poem. Thus in this passage Whitman emphasizes those aspects of the job that support his earlier vision of the grass as a natural e pluribus unum, where the individual leaf is as potent an image as an entire field, a condition that in turn supports his view that each person is unique yet connected to everything in the universe, and that all parts of that person-emotional, sensual and physical-form an indivisible whole.

This emphasis on seeing the holistic nature of the individual through the naturalness of all individuals' activities in turn allows Whitman to define "poet" as broadly as possible, and that definition extends to his concept of the poet's work. A poem is not simply a literary production; rather, says Whitman, the American people will read poetry seeking to find what they already know exists - "the path between reality and their souls" (10). Whitman therefore describes "poetical nature" (5) as a kind of energy with the potential to break down the boundaries between words 
and bodies, including bodies politic: "The United States themselves are essentially the greatest poem," he famously states in his Preface (5), and if his readers follow his precepts their "very flesh shall be a great poem" (11). Moreover it is the poet who must work to win his readers' understanding. In "Song of Myself," the speaker's ability to put the nation down on paper is a never-quite-attainable goal. Speech "provokes me forever," and, as the "twin of my vision" (53), must be invoked in the same way the speaker invokes his soul at the beginning of the poemhence the most ill-at-ease worker in "Song of Myself" is the "jour printer with gray head and gaunt jaws," whose eyes are "blurred with the manuscript" that he is setting in type (39), an individual on which the speaker displaces his anxiety that his own vision will remain untranslatable. Poetry is therefore not a literary production of an expert with the right word at the ready, but an attempt to "set" the essence of an event, and he who is closest to his own soul will in turn be most able to capture that essence in language so that it is immediately recognizable to his audience.

By theorizing poetry not as literary production for an enlightened few but as an energy available to all, and by beginning "Song of Myself" with a scene of summer indolence, Whitman challenges that ethic that saw virtue in hard work rewarded by material gain - "to do good by doing well." ${ }^{35}$ Thus the speaker begins his poem by separating himself from that work ethic at every class level, since at this point we know nothing about him except that if he has a job at all he's not doing it. Yet his lack of an identifiable occupation does not divide him from the kind of working class he creates as a counterbalance to the passive, Eurocentric cultivated classes. Instead, visionary loafers, artisans, laborers, frontiersmen, slaves, mothers, homemakers, historic figures and social outcasts all form what could be called a "cultivating class": all are workers not only because of the goods (or good) they produce but because they are described by the speaker of the poem at a moment in their work or lives when their situation "cultivates" an emotional response in the reader, drawing the "you" addressed by the speaker into the class as well, not merely through the pastime of reading but through active "filtering"-a word that gives interpretation the same natural overtones as the rest of the labor in the poem. Thus the poem's broadly-defined "common people" (6) stand not in opposition to economic wealth or power, nor in picturesque isolation from the reader, but as a unifying ideal: each individual connected to "Song of Myself"-Whitman, "I," subjects, and reader - contributes equally to its representation of America as "the greatest poem." ${ }^{36}$ For Whitman to create such a class, however, meant that he has to ignore those developments in his own time that point to growing disconnection between rich and poor, slave and free, North and South, and between competing reform movements and political ideologies. 
Thus Whitman removed his subjects to a "place" away from "the pulling and hauling" in order to preserve his own poetic role as the transcender of oppositions. Unfortunately, the United States proved not to be "the greatest poem" but a tangle of antagonisms intensified by party politics and reform movements. It was wild optimism to think that any poet or poem could mitigate against economic change or ease sectional conflict, yet Whitman continued to pursue that unified vision, ${ }^{37}$ although not with the confidence he had first shown. Between the lack of mass appreciation his work received and the increasing inter-regional turmoil that no poet could heal, he could no longer think of himself as his country's "largest lover and sympathizer" 38 until the Civil War brought him new figures to idealize - dying soldiers and a murdered presidentand a new job description as "The Good Gray Poet."

\section{Stow, Massachusetts}

\section{NOTES}

1 Walt Whitman, The Complete Writings, ed. Maurice Bucke et al. (New York: Putnam, 1902), 9:35-36.

2 Walt Whitman: Complete Poetry and Collected Prose, ed. Justin Kaplan (New York: Library of America, 1982), 5, 6. Page numbers of quotations will be noted parenthetically in the text. The 1855 version of "Song of Myself" was, of course, untitled and unsectioned, but, for ease of citation, I refer to the poem as "Song of Myself" and place passages in the familiar later fifty-two sections.

3 Whitman, Notebooks and Unpublished Prose Fragments, ed. Edward F. Grier (New York: New York University Press, 1984), 1:67.

4 David S. Reynolds, Beneath the American Renaissance (New York: Alfred A. Knopf, 1988), 510, 512. Reynolds discusses Whitman's use of the b'hoy character not only in the context of the development of the speaker of "Song of Myself," but also as the beloved "boy" of Whitman's later poems. For Whitman's incorporation of aspects of the loafer into his poetic persona, see Reynolds, Walt Whitman's America: A Cultural Biography (New York: Alfred A. Knopf, 1995), 64-65, 327, 345-346.

5 From an unsigned review in The Critic, London, England, 1855, quoted in Walt Whitman, Walt Whitman's Autograph Revision of the Analysis of Leaves of Grass (New York: New York University Press, 1974), 138n.

6 Betsy Erkkila, Whitman the Political Poet (Oxford: Oxford University Press, 1989), 76.

7 M. Wynn Thomas, The Lunar Light of Whitman's Poetry (Cambridge: Harvard University Press, 1987), 51.

8 "Personal history" as it applies to this passage has been broadly defined (the definition is also problematized by the fact that Whitman was himself a local public figure). Graham Clarke notes that much of Whitman's poetry avoids confronting the recent past, the better to focus on the possibilities he sees in his idealized present, while Reynolds discusses this passage as it pertains to Whitman's then current family and financial problems. See Graham Clarke, Walt Whitman: The Poem as Private His- 
tory (London: Vision Press, 1991), 13, and David S. Reynolds, Walt Whitman's America: A Cultural Biography (New York, Alfred S. Knopf, 1995), 330.

9 Erkkila, 76, 97.

10 The idea of "pulling and hauling" as an attempt to categorize the unique finds its expression in two 1850s developments. According to Sean Wilentz, the first detailed census of New York City manufacturers, listing occupations, shop sizes and wages, was made in 1850, an indication that government now preferred to define labor as measurable units rather than the work of individuals (see Sean Wilentz, Chants Democratic: New York City and the Rise of the American Working Class [Oxford: Oxford University Press, 1984], 398). Martin Klammer notes that the 1850 s marked the growing popularity for quasi-scientific explanations for racial differences and the innate superiority of northern Europeans, another aspect of pulling and hauling contradicted to some extent by Whitman's portrait of and identification with the black teamster in Section 13 (see Martin Klammer, Whitman, Slavery, and the Emergence of Leaves of Grass [University Park: Pennsylvania State University Press, 1995], 93, 131-132).

11 See, for instance, Thomas, 16-17, and Alan Trachtenberg, "The Politics of Labor and the Poet's Work: A Reading of 'A Song for Occupations"” in Ed Folsom, ed., Walt Whitman: The Centennial Essays (Iowa City: University of Iowa Press, 1994), 125.

12 Thomas, 82; Trachtenberg, 130.

13 Thomas, 147.

14 James Dougherty points out that for Whitman's intended 1855 readers the settings of many of these vignettes would have been familiar from genre paintings, lithographs, and other forms of popular pictorial art (Walt Whitman and the Citizen's Eye [Baton Rouge: Louisiana State University Press], 1993, 58-59).

15 Graham Clarke also sees the subjects of the poem as object "types"; his emphasis, however, is that Whitman's objectification of his characters is a function of how the speaker's gaze works as a form of desire. Clarke, 65 .

16 Thomas, 36.

17 Ralph Waldo Emerson, Essays, Second Series (Cambridge: Riverside Press, 1903), 13.

18 Joel Myerson notes that Whitman was extraordinarily involved in the design and production of his books, and speculates that Whitman may have "thought in print," based on his unique habit of having first drafts printed and then revising these proofs. See "Whitman: Bibliography as Biography," in Walt Whitman: The Centennial Essays, 21. Clarke also emphasizes how important printing and the building trades were to Whitman's development as a poet, 31 .

19 Quoted in Thomas, 118.

20 James Perrin Warren makes this point in relation to synthetic compound descriptions of occupations ("coon-seeker," "pike-fisher," etc.), yet came to a different conclusion, emphasizing that Whitman means to imply activity over permanent state, rather than activity as permanent state (Walt Whitman's Language Experiment [University Park: Pennsylvania State University Press, 1990], 55).

21 Thomas, 126, 244, and Trachtenberg, 124. 
22 My use of "containment" comes from Betsy Erkkila, who not only points out the impossibility of Whitman's "containing" and then presenting within his idealized America the figure of the slave master but also emphasizes how the speaker's presentation of a heterogeneous "multitude" obscures historically important racial and class inequities. Erkkila, 51, 102.

23 Michel Foucault, Discipline and Punish (New York: Vantage Press, 1979), 148.

24 Erkkila, 92.

25 David Reynolds notes, however, that Whitman was a highly inconsistent editorializer when it came to defining and proposing corrections for social problems (Beneath, 108).

26 Wilentz (383-384), for instance, details the New York City workers' associations agitation for a homestead act.

27 Maurice Kenny discusses Whitman's limited writings on Native Americans in "Whitman's Indifference to Indians," in Robert K. Martin, ed., The Continuing Presence of Walt Whitman: The Life After the Life (Iowa City: University of Iowa Press, 1992), 28-37. Thomas, 138-139.

28 Thomas, 138-139.

29 Charles T. Davis and Henry Louis Gates, Jr., The Slave's Narrative (Oxford: Oxford University Press, 1985), xv-xvi.

30 James Olney, "Slave Narratives: Their Status as Autobiography and as Literature," in Davis and Gates, 152-153. Olney lists the conventions for non-fiction escape narratives, including what he says is the obligatory Quaker reception, including "a lavish breakfast and much genial thee/thou conversation."

31 Martin Klammer (131-132) finds this identification of a white poet with black subjects an exceptionally radical act, and a rhetorical strategy that Whitman may have adopted from escape narratives themselves, especially Frederick Douglass's Narrative.

32 Thomas, 3.

33 Klammer (121) describes the people in these passages as "abstract, ghostly presences," but the haymaking farmers are more of an absence than a presence.

34 Trachtenberg, 129.

35 Eric Mottram, "Law and the Open Road: Whitman's 'America'" in NineteenthCentury American Poetry, ed. A. Robert Lee (London, Vision Press \& Barnes and Noble, 1985), 25.

36 Erkkila (91, 115-116) and Trachtenberg (125) both emphasize that Whitman saw the reader as an active interpreter, rather than a passive consumer of poetry.

37 For a discussion of how Whitman refigured the idea of work, trade, and slavery to mitigate against growing sectional conflict, see Thomas, "Whitman and the Dreams of Labor" in Walt Whitman: The Centennial Essays, 138, 141.

38 Walt Whitman, "Walt Whitman and His Poems," in Francis Murphy, ed., Walt Whitman: A Critical Anthology (Harmondsworth: Penguin Books, 1969), 35. 